Bangladesh J. Plant Taxon. 26(2): 179-182, 2019 (December)

(C) 2019 Bangladesh Association of Plant Taxonomists

\title{
NEW RECORDS OF PHYTOPLANKTON FOR BANGLADESH: DIVISION - CRYPTOPHYTA
}

\author{
Ashika Akhtar, Mst. Ayesha, Maliha Mehnaz, Md. Almujaddade Alfasane ${ }^{1}$ \\ AND Z.N. TAHMIDA BEGUM \\ Department of Botany, University of Dhaka, Dhaka 1000, Bangladesh
}

Key words: New records; Phytoplankton; Cryptophyta; Bangladesh.

\begin{abstract}
The paper records 6 species of freshwater phytoplankton from the algal Division Cryptophyta. The species are Cryptomonas pyrenoidifera Geitler, C. caudata Schiller, C. tetrapyrenoidosa Skuja, Chroomonas breviciliata Nygaard, C. reflexa Kiss. and Cyathomonas truncata (Fres.) Fisch HP. These are newly recorded species from Sylhet Division of Bangladesh.
\end{abstract}

\section{Introduction}

The algal division Cryptophyta contains a small group of biflagellate organisms which are dorsiventrally flattened, asymmetric and free swimming (Bold and Wynne 1985). Most of them are planktonic and commonly called cryptomonad algae. In Bangladesh, a number of studies were carried out on this phytoplankton (Islam and Khondoker, 1997; Khondoker et al., 2007; Alfasane et al., 2010; Gani et al., 2014). So far, a total of 9 genera and 19 species were reported (Ahmed et al., 2009).

The present authors while studying some samples of plankton collected from few oligo- to meso-eutrophic aquatic habitats of Sylhet and Moulvibazar districts recognized the occurrence of cryptomonads phytoplankton. Further detailed taxonomic study on the samples, 6 species were found belonging to the division Cryptophyta and hitherto reported as new to the list of cryptomonads from Bangladesh.

\section{Materials and Methods}

The samples for the present study were collected from different parts of Shari Goyain River and Piyain River of Sylhet district and Madhabpur Lake of Moulvibazar district. Some water quality characteristics of the studied habitats ranged: water temperature from $17.7-30.7^{\circ} \mathrm{C}, 17.1$ $31.3^{\circ} \mathrm{C}$ and $24.0-32.9^{\circ} \mathrm{C}$, respectively and $\mathrm{pH}$ from 6.8-8.9, 6.9-9.4 and 6.7-7.7, respectively. The samples of plankton were collected by hauling a plankton net of $20 \mu \mathrm{m}$ mesh size. After collection those were preserved in 5\% formalin. The microscopic study was performed with a Carl Zeiss Microscopy GmbH, Germany, Model: Axio Lab A1.

\footnotetext{
${ }^{1}$ Corresponding author: Email: <mujaddade@yahoo.com>
} 


\section{Taxonomy}

\section{Class: Cryptophyceae; Order: Cryptomonadales; Family: Cryptomonadaceae; Genus: Cryptomonas Ehrenberg}

1. Cryptomonas pyrenoidifera Geitler

(Fig. 1)

(Huber-Pestalozzi, 1968, 45, 64, Pl. 8, Fig. 47; Ling and Tyler, 2000, 57, Pl. 20, Fig. 8 )

Cell length $18-20 \mu \mathrm{m}$, breadth 7-8 $\mu \mathrm{m}$, in lateral elevation elliptic to approximately obovate, basal part broadly rounded. Cells are seen oblong elliptic to almost cylindrical towards the ends from the back.

Collection no. S-3(2), 04.08.2017, Shari Goyain River, Sylhet.

2. C. caudata Schiller

(Fig.2)

(Huber-Pestalozzi, 1968, 43, 54, Pl. 6, Fig. 30A)

Cell length $15-17 \mu \mathrm{m}$, breadth $8 \mu \mathrm{m}$, ovate in ventral view narrowing to the rear and suddenly into a small pointed flat appendages starting from the edge is visible. In the cross section almost circular, left lateral contour is stronger than the right curved.

Collection no. S-8(2), 05.08.2017, Shari Goyain River, Sylhet

3. C. tetrapyrenoidosa Skuja

(Fig. 3)

(Huber-Pestalozzi, 1968, 45, 62, Pl. 7, Fig. 45; Bourrelly, 1970, Pl. 1, Figs. 8-9)

Cell length 30-47 $\mu \mathrm{m}$, breadth 17-26 $\mu \mathrm{m}$, thickness 5-17 $\mu \mathrm{m}$, cells relatively large, oval, on one side convex than on the other, pressed together. Each chromatophore is usually provided with 2 pyrenoides on top of each other, sometimes ventral chromatophore lacks, the upper pyrenoid or pyrenoids are greatly reduced.

Collection no. P-9(3), 11.11.2017, Piyain River, Sylhet

\section{Class: Cryptophyceae; Order: Pyrenomonadales; Family: Chroomonadaceae; Genus: Chroomonas Hansgirg}

4. Chroomonas breviciliata Nygaard

(Huber-Pestalozzi, 1968, 27, 35, Fig. 22A)

Cell length 15-17 $\mu \mathrm{m}$, breadth 4-6 $\mu \mathrm{m}$, pear shaped, rounded front, pointed back and slightly pulled out to the side. Pyrenoid 2, equally long. Flagella very short. In the apical part furrow and granula lack a contractile vacuole.

Collection no. M-5(3), 12.11.2018, Madhabpur Lake, Moulvibazar, S-3(2), 04.08.2017, Shari Goyain River, Sylhet.

5. C. reflexa Kiss.

(Figs 5)

(Huber-Pestalozzi, 1968, 27, 32, 34, Pl. 3, Fig. 21)

Cell length $26-31 \mu \mathrm{m}$, breadth $15-16 \mu \mathrm{m}$, ovate with sharpened and background basal end, slope in front end.

Collection no. S-3(3), 10.11.2017, Shari Goyain River, Sylhet 

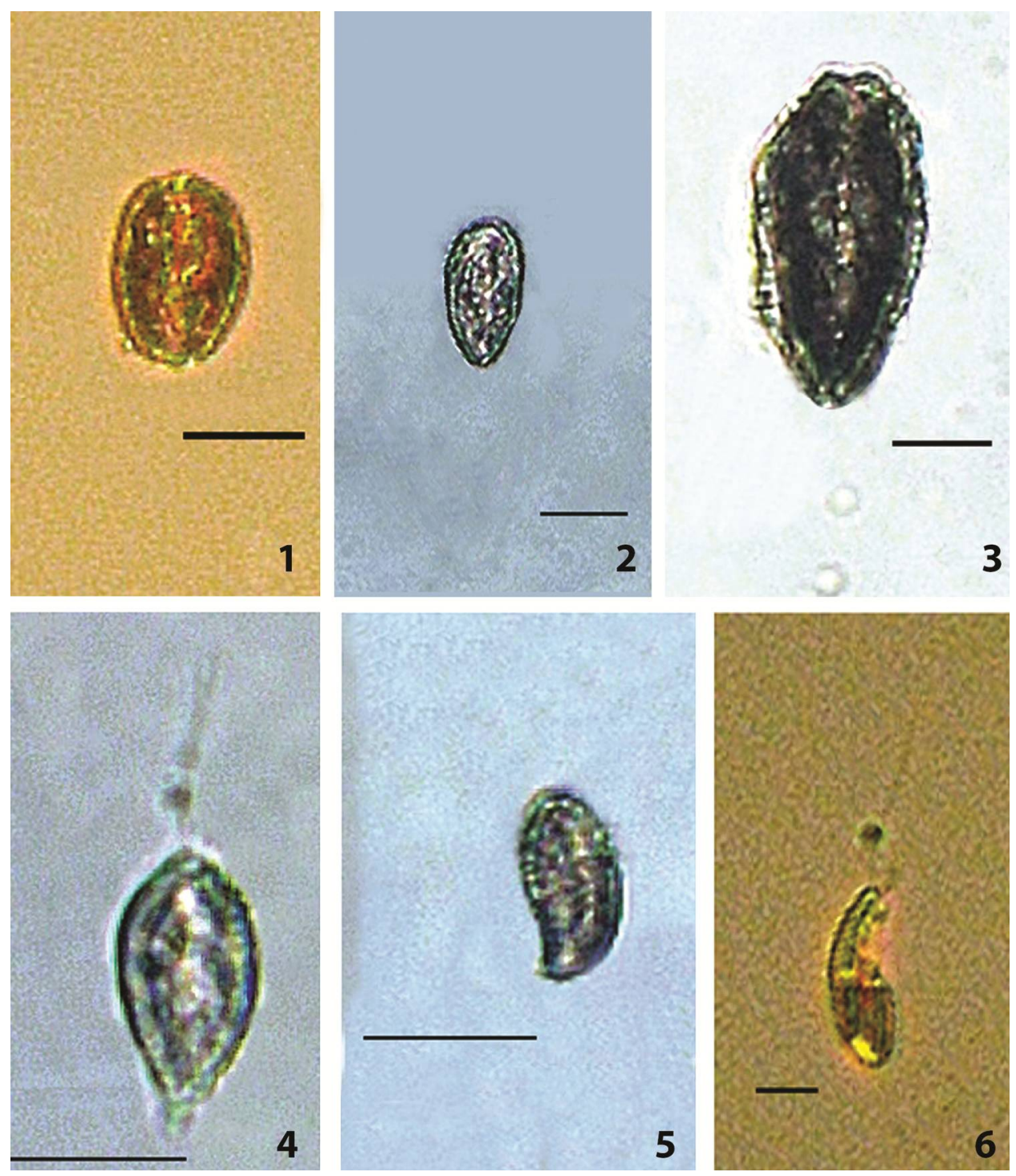

Figs 1-6. 1. Cryptomonas pyrenoidifera Geitler, 2. C. caudata Schiller, 3. C. tetrapyrenoidosa Skuja, 4. Chroomonas breviciliata Nygaard, 5. C. reflexa Kiss. 6. Cyathomonas truncata (Fres.) Fisch HP.

\section{Class: Cryptophyceae; Order: Pyrenomonadales; Family: Cyathomonadaceae; Genus: Cyathomonas Fromentel}

6. Cyathomonas truncata (Fres.) Fisch HP.

(Fig. 6)

(Huber-Pestalozzi, 1968, 15, 73, Pl. 10, Fig. 58a)

Syn. Goniomonas truncata (Fresenius) F. Stein 1878 
Cell length 15-30 $\mu \mathrm{m}$, cell a little less wide belly and back line in front and almost parallel in the middle. The contractile vacuole contracts in 3-4 times.

Collection no. S-3(2), 04.08.2017, Shari Goyain River, Sylhet.

\section{References}

Ahmed, Z.U., Khondker, M., Begum, Z.N.T., Hassan, M.A., Kabir, S.M.H., Ahmad, M., Ahmed, A.T.A. and Rahman, A.K.A. (eds) 2009. Encyclopedia of flora and fauna of Bangladesh. Vol. 4, Algae Cryptophyta - Rhodophyta (Achnanthaceae - Vaucheriaceae). Asiatic Society of Bangladesh, Dhaka. 543 pp.

Alfasane, M.A., Islam, M.S. and Khondker, M. 2010. Some freshwater phytoplankton as new reports from Bangladesh. Bangladesh J. Plant Taxon. 17(1): 87-92.

Bold, H.C. and Wynne, M.J. 1985. Introduction to the algae. Prentice Hall Inc., London. 720 pp.

Bourrelly, P. 1970. Les Algues d'eau Douce. Initiation à la Systématique. Tome III : Les Algues bleues et rouges Les Eugléniens, Peridiniens et Cryptomonadines. Edutions N Boubée \& Cie. J. 3 Place SaintAndré-des-Arts, Paris-VI. 512 pp.

Gani, M.A., Alfasane, M.A. and Khondker, M. 2014. New records of phytoplankton from wastewater lagoons of Pagla, Bangladesh. Bangladesh J. Bot. 43(1): 87-90.

Huber-Pestalozzi, G.H. 1968. Das Phytoplankton des Süßswassers. Systematik und Biologie. Teil. 3: Cryptophyceae, Chloromonadophyceae, Dinophyceae. E. Schweizerb. Verlagsb. (Nägele u. Obermiller), Stuttgart, Germany. pp. 322.

Islam, A.K.M.N. and Khondker, M. 1997. New records of some flagellate algae for Bangladesh. 5. Chlamydomonas, Pascherina, Pyrobotrys, Cryptomonas and Chilomonas. Bangladesh J. Plant Taxon. 4(2):13-23.

Khondoker, M., Bhuiyan, R.A., Yeasmin, J., Alam, M., Sack, R.B., Huq, A. and Colwell, R.R. 2007. New records of phytoplankton for Bangladesh. 2. Cryptophyceae and Synurophyceae. Bangladesh J. Bot. 36(1): 53-59.

Ling, H.U. and Tyler, P.A. 2000. Australian freshwater algae (exclusive of diatoms). Bibl. Phycol. 105. J Cramer, Berlin. 643 pp. 